DOI: https://doi.org/10.24144/2409-6857.2021.1(57).134-140

УДК 330:368.91

Тимчак М.В., Мінкович В.T.

\title{
ЄВРОПЕЙСЬКИЙ ДОСВІД СТРАХУВАННЯ ЖИТТЯ ТА МОЖЛИВІСТЬ ЙОГО ІМПЛЕМЕНТАЦІї В УКРАЇНІ
}

\begin{abstract}
На європейському страховому ринку страхування життя позиціонується як один з найбільш представницьких та розвинутих видів страхування як з точки зору соціально-економічної значущості, так $i$ з точки зору обсягу коштів, щчо обертаються. Мета статmі - вивчення європейського досвіду страхування життя $і$ дослідження можливостей його імплементаџії в Україні. Розглянуто основні показники європейського ринку страхування життя (страхові виплати, страхові премї, щільність страхування, проникнення страхового ринку) та їх динаміку. 3'ясовано, щзо сектор страхування життя y 2019 р. інвестував в економіку €700 млрд., щчо свідчить про його цінність для стабільного, довгострокового фінансування
\end{abstract}

Ключові слова: страхування життя, страховий поліс, страхова компанія, страхувальник, страховий ринок.

Постановка проблеми. Акумулювання страховими компаніями значних фінансових ресурсів та активна інвестиційна політика перетворюють страхування на потужний чинник розвитку економіки. Страхування життя важлива складова страхового бізнесу. На європейському страховому ринку страхування життя позиціонується як один 3 найбільш представницьких та розвинутих видів страхування як 3 точки зору соціальноекономічної значущості, так і з точки зору обсягу коштів, що обертаються. Оскільки договори страхування життя, як правило, укладаються на тривалий термін, то зібрані кошти можуть інвестуватися у довгострокові проекти.

Останнім часом у страховому секторі розвинених країн Європи почали відбуватися суттєві зміни. Страхові компанії активно розширюють межі своєї діяльності, виходячи на фінансові ринки не тільки як інвестори, але і в якості керуючих активами або емітентів цінних паперів. Це дає можливість страховому сектору виступати у соціальній сфері вже не просто гарантом стабільності, але й джерелом створення додаткового доходу для широких верств населення завдяки наданню клієнтам інвестиційних інструментів (продуктів 3 інвестиційною складовою). Актуальність теми

(СТимчак М.В., к.е.н., доц., доцент кафедри фінансів і банківської справи, ДВНЗ «Ужгородський національний університет, м. Ужгород, E-mail: maryana.tymchak@uzhnu.edu.ua Мінкович B.T., старший викладач кафедри фінансів і банківської справи, ДВНЗ «Ужгородський національний університет, м. Ужгород, E-mail: victoria.minkovych@uzhnu.edu.ua зумовлена необхідністю наближення практики страхування життя в Україні до норм європейського страхового ринку.

Аналіз останніх досліджень і публікацій. Проблематика страхування життя викликає широкий інтерес серед науковців. Окремі аспекти страхування життя відображені у наукових працях як зарубіжних, так і вітчизняних вчених. Зокрема, Ермасов С.В., Ермасова Н.Б., Князєва Є.Г., Журавка О.С., Бухтіарова А.Г, Пахненко О.М. розглянули теоретичні основи функціонування страхування життя як елементу особистого страхування; Офутін А. досліджує тенденції розвитку продуктів Unit-Linked в Европі в умовах фінансової кризи; Криклій А.С., Волохова Л.Ф., З Захаренко В.В. вивчають зарубіжний досвід розвитку ринку страхування. Разом 3 тим, питання імплементації європейського досвіду страхування життя в Україні залишаються актуальними і потребують подальшого дослідження.

Мета статті - вивчення європейського досвіду страхування життя і дослідження можливостей його імплементації в Україні.

Постановка проблеми. Страхування життя $\epsilon$ важливим інструментом соціального захисту населення і джерелом інвестування національних економік. Це найбільш доступний спосіб забезпечення гарантій захисту економічних інтересів людей, відшкодування втрат у їх доходах у зв'язку із втратою здоров'я або смерті члена родини, надання медичної допомоги у випадку захворювання [5].

Поступова інтеграція України до європейських структур вимагає дослідження європейського ринку страхування життя та поширених на ньому програм страхування. 
У 2019 р. європейський страховий сектор інвестував в економіку більше $€ 10,4$ трлн., що демонструє цінність галузі у стабільному, довгостроковому фінансуванні економіки. Загальна сума валових страхових премій у 32 країнах Європи склала понад $€ 1,2$ трлн. Впродовж року відбувалося стабільне зростання майнового страхування $(+2,2 \%)$, медичного страхування $+6,8 \%)$ та страхування життя $(+4,7 \%)$. У таблиці 1 наведено основні показники, що характеризують європейський ринок страхування життя.

Таблиця 1

Основні показники європейського ринку страхування життя [1]

\begin{tabular}{|c|c|c|c|c|}
\hline 2018 & 2019 & Зростання & $\begin{array}{c}2019 \\
\text { (без Великої Британії) }\end{array}$ & $\begin{array}{c}\text { Зростання } \\
\text { (без Великої Британіi) } \\
\end{array}$ \\
\hline \multicolumn{5}{|c|}{ Страхові виплати } \\
\hline$€ 702$ bn & $€ 630 \mathrm{bn}$ & $\downarrow-10.8 \%$ & $€ 484 \mathrm{bn}$ & $\uparrow 6.3 \%$ \\
\hline \multicolumn{5}{|c|}{ Страхові премії } \\
\hline$€ 753 \mathrm{bn}$ & $€ 700 \mathrm{bn}$ & $\downarrow-7,5 \%$ & $€ 547 \mathrm{bn}$ & $\uparrow 4,7 \%$ \\
\hline \multicolumn{5}{|c|}{ Щільність страхування } \\
\hline$€ 1262$ & $€ 1163$ & $\downarrow-7,9 \%$ & $€ 1022$ & $\uparrow 4,3 \%$ \\
\hline \multicolumn{5}{|c|}{ Проникнення страхового ринку } \\
\hline $4.41 \%$ & $3.95 \%$ & $\downarrow-0,46 \mathrm{pp}$ & $3,60 \%$ & $\uparrow 0,06$ п.п. \\
\hline
\end{tabular}

У 2019 р. страхові виплати становили €630 млрд., або €1046 на душу населення і порівняно 3 2018 р. зменшились на 10,8\%. Причиною такого різкого падіння було зменшення страхових виплат $(-41,8 \%)$ та страхових премій (-34,8\%) у Великій Британії, пов’язане з тим, що результати кількох британських страхових компаній, що здійснюють страхування життя, не були включені до показників ABI; із змінами у структурі бізнесу окремих компаній; зменшенням пенсійних виплат. Якщо аналізувати страхові виплати без показників Великої Британії, то у 2019 р. вони зросли на $6,3 \%$ i становили $€ 484$ млрд., а в перерахунку на душу населення $€ 902$.

У 2019 р. 68,2\% усіх страхових виплат припадало на чотири найбільші ринки Великобританія, Франція, Німеччина та Італія. Зменшення страхових виплат на 5,5\% відбулось через їх зменшення у Великій Британії. Інші три ринки продемонстрували значне зростання виплат: Німеччина $(+7,4 \%)$, Італія $(+5,5 \%)$ та Франція $(+3,8 \%)$. Страхові виплати зросли й на менших ринках, зокрема: Швеція $(+38,7 \%)$, Фінляндія (+17,4\%), Угорщина (+14\%), Австрія $(+9,5 \%)$. Разом 3 тим, у деяких країнах зафіксовано зниження виплат: Греція $(-24,7 \%)$, Португалія (-11,9\%), Польща (-13,6\%).

Страхові премії в Європі становили $€ 700$ млрд. Зменшення на 7,5\% порівняно з 2018 р. пов'язане iз їх зниженням у Великій Британії $(-34,8 \%)$. Якщо не включати показники Великої Британії, то страхові премії зросли на 4,7\% і становили $€ 547$ млрд. 76,3\% страхових премій припадало на ринки Великої Британії, Франції, Італії, Німеччини та Іспанії. Збільшення страхових премій мало місце у Фінляндії $(+13,1 \%)$, Німеччині $(+11,5 \%)$, Угорщині $(+6,8 \%)$, Бельгії (+ 4,4\%), Франції (+3,5\%); зменшення - у Португалії $(-13,7 \%)$, Чехії (-13\%), Іспанії $(-5,6 \%)$, Австрії (2,1\%), Польщі (-2\%).

Щільність страхування (відношення валових страхових премій до загальної чисельності населення) $є$ індикатором споживання страхування на душу населення. У 2019 р. середній показник по Європі становив €1663 на душу населення, що на 7,9\% менше порівняно 3 2018 p.

Проникнення страхового ринку (відношення обсягу страхового ринку до загального ВВП країни) показує частку страхових послуг в економіці країни (у відсотках). Даний показник у 2019 р. становив 3,95\% і порівняно 32018 р. зменшився на 0,46 п.п. [1].

В Свропі поширені такі програмами страхування життя:

1. Ризикове страхування життя - страховий поліс оформляється на короткий термін (зазвичай не більше 1 року). Клієнт страхує своє життя від можливої хвороби, нещасного випадку, травми, смерті і т.п. Принцип дії ризикового страхового полісу полягає в тому, що клієнт одноразово сплачує фіксовану суму в страхову компанію, а страхова компанія зобов'язується виплатити клієнтові певну компенсацію, якщо з клієнтом відбудеться вказаний у полісі страховий випадок. Якщо за період, на який клієнт застрахувався, 3 ним не відбувся страховий випадок, то термін дії полісу закінчується і жодних виплат клієнт не отримує, тобто гроші (вартість полісу) залишаються у страхової компанії. 
2. Накопичувальне страхування життя - це довгострокове страхування життя (зазвичай від 10 років i більше), при якому клієнт не тільки захищений від певних ризиків, а ще має можливість накопичити та примножити свої кошти. Страхові компанії надають різні варіанти цього продукту з покриттям різних видів ризику, але в програму накопичувального страхування обов'язково входять ризики дожиття застрахованої особи до закінчення терміну дії договору і смерть застрахованої особи. У першому випадку клієнт отримує всю страхову суму, визначену договором плюс додатковий інвестиційний дохід, (відсотки, нараховані на внесені клієнтом кошти). У другому випадку страхову суму і додатковий інвестиційний дохід отримує вигодонабувач (спадкоємець), вказаний у договорі страхування. У Європі 80\% населення мають поліс накопичувального страхування. Поряд 3 накопичувальним страхуванням життя поступово набирають популярність комбіновані страхові продукти із сервісною складовою (послуги телемедицини, медичні чек-апи та ін.). Для клієнта це, як правило, приємна дрібничка, яка підвищує лояльність до страхової компанії.

3. Змішане страхування життя - симбіоз двох попередніх видів страхування життя, при якому встановлюються як основні (дожиття або смерть застрахованої особи), так і додаткові (критичні захворювання, травма, інвалідність) ризики. Поліс гарантує матеріальне забезпечення двох і більше страхових випадків, при настанні яких страхова компанія виплачує відшкодування.

4. Страхування життя за участю в прибутку компанії (With-Profits Policies). Після проведення щорічної оцінки страхових активів і пасивів компанія відраховує частину прибутку у вигляді бонусу на користь страхувальника. Бонус підлягає виплаті тільки після закінчення договору.

5. Страхування життя за участю в резервному капіталі покриття - до складу страхової премії включається певний норматив заощаджень, який страхова компанія інвестує, тим самим формується резервний капітал покриття. Прибутковість за такими договорами невисока [10; 69-70].

6) Інвестиційне страхування життя (UnitLinked) $\epsilon$ гібридом класичного накопичувального страхування життя з інвестиційною складовою у вигляді пайових фондів (поєднує риси страхового та інвестиційного продукту). У 2018 р. на цей продукт припадало $73 \%$ обсягу європейського страхового ринку. Визнаним лідером $\epsilon$ Великобританія.
Інвестиційні поліси призначені для клієнтів, яких у першу чергу цікавить не страховий захист, а створення капіталу і отримання додаткового доходу. Поліси Unit-Linked $\epsilon$ серйозною альтернативою продуктам банків та інвестиційних компаній, оскільки, з одного боку, полегшують індивідуальним інвесторам їх участь в операціях на фондовому ринку, а з іншого - ще й надають необхідні страхові гарантії [3;33].

За програмою страхування життя Unit-Linked вкладені кошти діляться на дві частини: гарантійний та інвестиційний фонд. Одна частина інвестується в інструменти 3 фіксованою прибутковістю. Вони підбираються таким чином, щоб до моменту закінчення терміну страхового полісу забезпечити повернення повної страхової суми (ця частина забезпечує захист капіталу). 3 другої, інвестиційної частини, здійснюються ринкові операції, що дозволяють отримати додатковий дохід від розміщення у більш ризикові і потенційно прибуткові фінансові інструменти (акції, облігації, взаємні фонди).

Пропорція між цими двома частинами не фіксована. Коли ринок росте, страхова компанія збільшує інвестиційний фонд, що дозволяє клієнтам отримати додатковий прибуток. При падінні ринку значна частина інвестицій клієнта переходить у консервативні інструменти i забезпечує повернення грошових коштів (ребалансування). Клієнт може самостійно вибрати стратегію інвестування, яка визначає співвідношення між частками вкладень у гарантійний та інвестиційний фонд при збереженні гарантії повернення інвестицій.

У даному сегменті зустрічаються поліси 3 гарантованою прибутковістю (близько 2-3\% в доларах), але в більшості випадків прибутковість заздалегідь не визначена і залежить від ситуації на фондовому ринку, а також від характеру обраної стратегії. Необмежена прибутковість зумовлює і більш високі ризики. Проте захист вкладеного капіталу у вигляді страхової премії повністю зберігається. Гарантія вкладеної клієнтом премії забезпечується платоспроможністю страхової компанії, що жорстко контролюється регулятором [11].

Після закінчення терміну дії полісу клієнт отримує суму, яка за час інвестування може суттєво збільшитися за рахунок зростання вартості цінних паперів. При настанні страхового випадку вигодонабувач отримує страхові виплати у розмірі страхової суми і суми інвестицій. Власник полісу, по суті, отримує можливість інвестувати свої накопичення, отримувати дохід від такого інвестування i при цьому бути застрахованим. 
Цільова прибутковість за продуктами інвестиційного страхування життя зазвичай вища, ніж прибутковість депозитів. Однак гарантій тут немає: все залежить від ризик-апетиту клієнта, який приймає рішення щодо продукту та інвестиційних інструментів. Особливість UnitLinked саме в тому i полягає, що не можна заздалегідь назвати середню прибутковість, оскільки вона залежить від базових активів.

На відміну від класичного накопичувального страхування з гарантованою прибутковістю, при якому інвестиційна стратегія, як правило, консервативна i зав'язана на боргових цінних паперах 3 високим рейтингом, Unit-Linked дає можливість клієнтам самостійно обирати стратегію і бути вільними від консерватизму страхових компаній. Поліс Unit-Linked більш прозорий: у ньому чітко визначені основні елементи страхової премії (інвестиції, ризикові премії і витрати).

У чистих продуктах Unit-Linked інвестиційний ризик, пов'язаний із вкладенням коштів у більш дохідні і одночасно більш ризикові інструменти, а також повернення коштів перекладаються на власника поліса. При цьому роль страхової компанії зводиться до забезпечення гарантованого рівня страхового захисту i здійснення адміністрування фінансових вкладень клієнта до фондів.

3 метою зменшення інвестиційних ризиків клієнтів страхові компанії розробляють альтернативні страхові продукти Unit-Linked:

1. Гарантовані продукти пропонують доступ до гарантованого інвестиційного фонду, який надає гарантію капіталу. 3 метою збереження встановленого рівня захисту капіталу здійснюється постійне перебалансування фонду між активами із високим і низьким рівнем ризику.

2. Індексовані продукти пропонують повернення страхової премії і (або) мінімальне гарантоване повернення із зазначеною датою виконання. Доходи від інвестицій пов'язані 3 поведінкою індексу або цінних паперів.

3. Гібридні продукти пропонують поєднання інвестицій у традиційний i Unit-Linked продукт.

4. Продукти 3 додатковими гарантіями (Variable annuity - плаваючий ануїтет) - вид гарантованого Unit-Linked продукту, величина виплат за яким може час від часу змінюватися. Зокрема, коли за умовами договору страхова компанія інвестує кошти клієнта у цінні папери. Оскільки вартість і прибутковість цінних паперів може коливатися в часі, то суми ануїтетних виплат можуть змінюватися. Продукт пропонує вибір факультативних інвестиційних гарантій. До найбільш поширених гарантій належать: гарантований мінімум викупної суми, гарантований мінімум виплати по доходах, гарантований мінімум виплати по накопиченню, гарантований мінімум посмертної виплати. Гарантії прикріплені до полісу страхування життя, а не до окремих фондів. Змінні ануїтети дають можливість страховим компаніям задовольнити потреби клієнта шляхом комбінування вигод потенційно високих прибутків від інвестицій із гарантіями, які захищають клієнтів від впливу сильних ринкових падінь [7].

Останнім часом на європейському страховому ринку з'явилися i успішно продаються нові продукти, які надають страхувальнику повну свободу щодо вибору, зміни і доповнення умов страхування життя. Першим 3 таких продуктів був поліс вільного страхування - «універсальне життя» (Universal Life). Основна ідея цього виду страхування полягає в тому, що страхувальник, укладаючи договір, залишає за собою право вільного режиму оплати премій як за термінами, так i за розмірами, а також вільного вибору гарантій впродовж терміну дії договору. Залежно від фактично сплачених страхових внесків і змін у вимогах страхувальника до набору страхових виплат, страхова компанія постійно корегує страхові суми. Договори такого роду поєднують фінансовий, ощадний і власне страховий продукт, оскільки їх основною метою $\epsilon$ створення i накопичень, і отримання страхової гарантії.

Впродовж терміну дії договору страхувальник має право у будь-який момент внести у поліс додаткові гарантії, чи отримати кошти з ощадного рахунка, внести додаткові одноразові премії, чи змінити страхову суму на випадок смерті. Крім основних виплат на дожиття і смерть у таких полісах пропонуються такі гарантії: виплата регулярного доходу; допомога при постійній втраті здоров'я; страхова сума на випадок інвалідності; допомога на утримання в лікарні; підвищена виплата на смерть в результаті нещасного випадку; покриття на випадок діагностування критичних захворювань [3; 36].

У європейській практиці страхування максимально деталізуються вимоги до продуктів страхування життя щодо прозорості умов i однозначності трактування договорів страхування, щодо складу інформації, що надається страховиком клієнтові, регулярності іiі надання. У Великій Британії діє інститут фінансових омбудсменів, які вирішують суперечки між страховою компанією і клієнтом у разі місселінгу (Mis-selling - недобросовісний продаж). У Німеччині діє інститут незалежних спілок споживачів, що надає безкоштовні 
консультації клієнтам 3 будь-яких питань, пов'язаних 3 придбанням фінансових послуг. У Нідерландах клієнту обов'язково надають пам'ятку з основними параметрами за договором. Багато європейських країн мають податкові пільги при здійсненні страхових виплат (Австрія, Бельгія, Данія, Іспанія, Нідерланди, Фінляндія, Франція, ФРН, Швейцарія).

Процес інтеграції України до $\mathrm{CC}$ вимагає приведення законодавства України у відповідність до законодавства ЄС. Метою регуляторного наближення в секторі страхових послуг $\epsilon$ запровадження повного режиму внутрішнього ринку $\epsilon \mathrm{C}$, що дозволить українським страховим компаніям надавати послуги в $\mathrm{CC}$ на тій же основі, що й компаніям 3 країн CC.

Уніфікація національних систем регулювання страховою діяльністю здійснюється на основі основних принципіп, які декларовані Другою директивою 3 платоспроможності страхових i перестрахувальних компаній країн $6 \mathrm{C}$ (Solvency II) та вимогами Міжнародної асоціації органів страхового нагляду (IAIS). Фрагментованість регулювання перешкоджає міжнародній експансії.

Реалізація вимог Solvency II може призвести до зростання попиту на угоди, що передбачають спрощені вимоги до обсягу капіталу для страхових компаній із більш високим рівнем платоспроможності. Однак запізніле впровадження цих вимог зменшує затребуваність таких продуктів на ринку [2].

Завданням адаптації законодавства України про страхові послуги до законодавства ЄС $€$ уніфікація європейської та української юридичної термінології, а також внесення змін та/або доповнень до відповідних нормативних актів. Якщо в Україні відсутні правові акти, необхідні для правового врегулювання певних відносин у сфері страхування, а таке регулювання передбачене директивами $\mathrm{CC}$, то вони мають бути розроблені і запроваджені. Слід зазначити, що основна робота щодо наближення вітчизняного законодавства із страхування знаходиться лише на стадії розробки та опрацювання відповідних законопроектів.

Регулювання відносин між страховиком i страхувальником у сфері страхування життя відбувається на підставі Закону України «Про страхування» від 7 березня 1996 р. № 85/96-вр 3 урахуванням останніх коригувань від 10 грудня 2020 p. [8].

Слід зазначити, що страхування життя в Україні має значний потенціал розвитку, оскільки його метою є доповнення системи соціального забезпечення. За період з 2009 по 2019 рр. обсяги надходжень страхових премій на ринку страхування життя зросли майже в 4 рази, страхових виплат в 6,8 разів. За 9 місяців 2020 р. обсяги премій зі страхування життя порівняно 3 аналогічним періодом 2019 р. зросли на 10\% i склали 3,6 млрд. грн. На страховому ринку на кінець 2020 р. працювало 20 страхових компаній, що займалися страхуванням життя. За січеньвересень 2020 р. страхові компанії виплатили клієнтам понад 438,2 млн. грн. До ТОП страховиків життя 9М2020 за преміями належать МЕТЛАЙФ - 1092299 тис. грн., ТАС - 483834 тис. грн., УНІКА Життя - 459444 тис. грн., PZU Україна страхування життя - 391202 тис. грн., ACKA-Життя 301907 тис. грн., ARX LIFE 192784 тис. грн., Грінвуд Лайф Іншуранс - 64618 тис. грн., КД-Життя - 34369 тис. грн., ІНГО Життя - 26714 тис. грн. [9].

В Україні популярні види страхування життя, що мають ощадну функцію: змішане страхування життя, страхування дітей, страхування до одруження, довічне страхування. Серед видів страхування, що базуються на механізмі страхування рент (ануїтетів), найбільш поширені продукти, призначені для одержання освіти, купівлі нерухомості (житла) й виплати додаткової пенсії [4; 153].

Вивчаючи поточні тенденції на ринку, страхові компанії, що займаються страхуванням життя модифікують продуктову лінійку страхових продуктів, пропонуючи стратегії, адаптовані під невеликий ріст. Наголос робиться на продуктах, розрахованих на великий гарантований дохід, а не на потенційний ріст ринку. Впровадження в Україні Unit-Linked може надати додаткового імпульсу ринку інвестиційного страхування життя, стати джерелом якісно нових продуктів накопичувального та пенсійного страхування. У той же час, Unit-Linked $\epsilon$ високоризиковим інструментом, тому його впровадження вимагає прийняття відповідної нормативно-правової бази і якісного опрацювання.

Розвиток класичного страхування життя в Україні гальмується низьким рівнем доходів і страхової культури значної частини населення, недовірою до непрозорого ринку страхування та фінансової системи в цілому, відсутністю дієвого механізму захисту прав споживачів страхових послуг, фінансовою необізнаністю громадян у страхових продуктах [6]. До того ж, значна частина населення все ще сподівається на підтримку держави, тому не вважає необхідним самостійно здійснювати страховий захист, незважаючи на факти, які свідчать про 
протилежне. Тому актуальною залишається проблема підвищення рівня обізнаності населення про роль і важливість страхування життя.

В Україні не існує механізму гарантування страхових виплат за договорами довгострокового страхування життя, що $€$ однією 3 причин непопулярності цього виду страхування. Діюча процедура виходу 3 ринку не захищає прав споживачів страхових послуг. Через свою недосконалість i довготривалість вона дає можливість недобросовісним страховим компаніям вийти 3 ринку, не виконавши свої зобов' язання за договорами страхування [6].

Запровадження карантину дало поштовх стрімкому розвитку електронної комерції у страхуванні, що починає конкурувати 3 класичними територіальними мережами продажів та стає їх невід'ємною складовою.

Висновки та перспективи подальших досліджень. За результатами проведеного дослідження можна зробити висновок, що сектор страхування життя $є$ важливим чинником економічного розвитку країн та інструментом вирішення багатьох соціальних проблем.

Запровадження правил страхового ринку ЄС та наближення вітчизняного законодавства із страхування життя до законодавства, що регулює страхову діяльність у країнах ЄС 3 часом дасть можливість запровадити режим внутрішнього ринку ЄС.

Подальший розвиток ринку страхування життя в Україні експерти пов'язують із впровадженням продукту Unit-linked. У Європі інвестиційне страхування життя розвивається навіть більш активно, ніж класичні види страхування життя. Страхові компанії зацікавлені у наданні нової для України фінансової послуги - інвестиційного страхування, - що дозволить їм вийти на додаткові сегменти ринку i залучити клієнтів набагато швидше.

Перспективи подальших наукових розвідок у даному напрямку вбачаються у дослідженні функціонування ринку страхування життя в умовах пандемії COVID-19.

\section{СПИСОК ВИКОРИСТАНИХ ДЖЕРЕЛ}

1. European Insurance in $\quad$ Figures 2019 data.

URL:https://www.insuranceeurope.eu/sites/default/files/attachments/EIF\%202021_0.pdf. (дата звернення 18.04.2021).

2. Волохова Л.Ф., Захаренко В.В. Зарубіжний досвід розвитку ринку страхування життя як чинник впливу на українські реалії. Науковий вісник Міжнародного гуманітарного університету. Серія: Економіка і менеджмент. 2019. Вип. 35. С. 137-142.

3. Ермасов С.В., Ермасова Н.Б. Страхование. В 2 частях. Часть 2. М.: Издательство «Юрайт». 2018.244 с.

4. Журавка О.С., Бухтіарова А.Г, Пахненко О.М. Страхування: навчальний посібник. Суми: Сумський державний університет. 2020. 350 с.

5. Криклій А.С. Ринок страхування життя в Україні: тенденції та європейський досвід. Економіка та держава. 2008. № 5. С. 14-16.

6. Майбутнє регулювання ринку страхування в Україні. Біла книга. Національний банк України. Київ. 2020.28

c. URL:https://bank.gov.ua/admin_uploads/article/White_paper_insurance_2020.pdf?(v =4 (дата звернення 20.04.2021).

7. Офутин А. Тенденции развития продуктов unit-linked в Европе в условиях финансового кризиса. URL:https://forinsurer.com/public/09/03/26/3722 26.03.2009 (дата звернення 20.04.2021).

8. Про страхування: Закон України від 7 березня 1996 року № 85/96-BP / Верховна Рада України. URL: https://zakon.rada.gov.ua/laws/show/85/96-\%D0\%B2\%D1\%80\#Text (дата звернення 19.04.2021).

9. Рейтинг компаний страхования жизни. URL:https://forinsurer.com/ratings/life (дата звернення 20.04.2021).

10. Страхование: учебник / под ред. Е.Г. Князевой. Екатеринбург: Изд-во Урал. ун-та. 2019. 242 с.

11. Финансовые продукты с защитой капитала: основные виды.

URL:http://fingramota22.ru/materials/base/material.php?ID=210 (дата звернення 19.04.2021).

\section{REFERENCES}

1. European insurance Figures 2019 data. Available https://www.insuranceeurope.eu/sites/default/files/attachments/EIF\%202021_0.pdf (accessed 18 April 2021).

2. Volokhova L.F., Zakharenko V.V. (2019). Zarubizhnyi dosvid rozvytku rynku strakhuvannia zhyttia yak chynnyk vplyvu na ukrainski realii [Foreign experience in the development of the life insurance market as a factor influencing Ukrainian realities]. Naukovyi visnyk Mizhnarodnoho humanitarnoho universytetu. Seriia: Ekonomika i menedzhment. Vol. 35. pp. 137-142 [in Ukrainian].

3. Ermasov S.V., Ermasova N.B. (2018). Strahovanie. V 2 chastjah. Chast' 2 [Insurance. In 2 parts. Part 2]. M.: Jurajt. 244 s. [in Russian].

4. Zhuravka O.S., Bukhtiarova A.H, Pakhnenko O.M. (2020). Strakhuvannia: navchalnyi posibnyk [Insurance]. Sumy: Sumskyi derzhavnyi universytet. 350 s. [in Ukrainian]. 
5. Kryklii A.S. (2008). Rynok strakhuvannia zhyttia v Ukraini: tendentsii ta yevropeiskyi dosvid [Life insurance market in Ukraine: trends and European experience]. Ekonomika ta derzhava. No 5. pp. 14-16 [in Ukrainian].

6. Maibutnie rehuliuvannia rynku strakhuvannia v Ukraini. Bila knyha (2020) [Future regulation of the insurance market in Ukraine. White book]. Natsionalnyi bank Ukrainy. Kyiv. 28 s. Available at: https://bank.gov.ua/admin_uploads/article/White_paper_insurance_2020.pdf?(v =4 (accessed 20 April 2021).

7. Ofutin A. Tendencii razvitija produktov unit-linked $v$ Evrope $v$ uslovijah finansovogo krizisa (2009) [Trends in the development of unit-linked products in Europe during the financial crisis]. Available at: https://forinsurer.com/public/09/03/26/3722 26.03.2009 (accessed 20 April 2021).

8. Pro strakhuvannia: Zakon Ukrainy (1996) [About insurance: Law of Ukraine]. Verkhovna Rada Ukrainy. Available at: https://zakon.rada.gov.ua/laws/show/85/96-\%D0\%B2\%D1\%80\#Text (accessed 19 April 2021).

9. Rejting kompanij strahovanija zhizni (2020) [Rating of life insurance companies]. Available at: https://forinsurer.com/ratings/life (accessed 20 April 2021).

10. Strahovanie (2019) [Insurance] / pod red. E.G. Knjazevoj. Ekaterinburg: Izd-vo Ural. un-ta. 242 s. [in Russian].

11. Finansovye produkty s zashhitoj kapitala: osnovnye vidy (2021) [Financial products with capital protection: main types]. Available at: http://fingramota22.ru/materials/base/material.php?ID=210 (accessed 19 April 2021).

Отримано 20.02.2021 